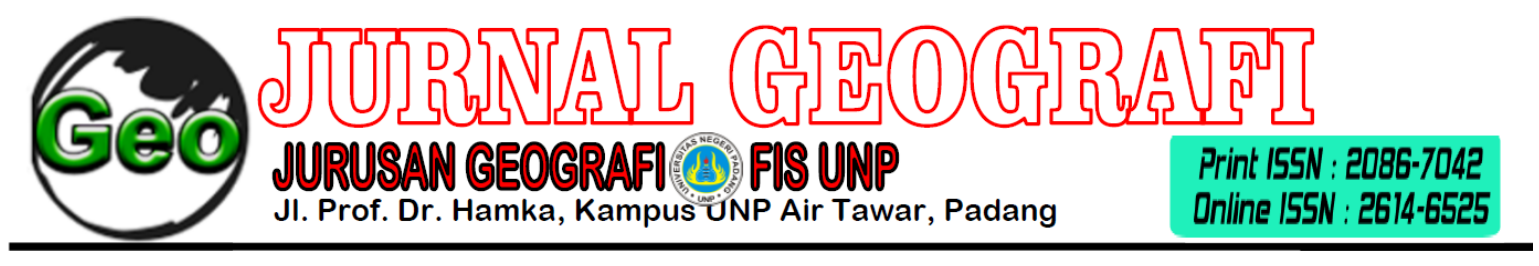

\title{
DAMPAK KEBERADAAN KAMPUS INSTITUT AGAMA ISLAM NEGERI (IAIN) BUKITTINGGI TERHADAP PERUBAHAN PEMANFAATAN LAHAN DI WILAYAH SEKITARNYA
}

\author{
Ridwandi $^{1}$,Ahyuni ${ }^{2}$, Ratna Willis ${ }^{2}$ \\ Program StudiGeografi \\ Fakultas Ilmu Sosial, Universitas Negeri Padang \\ Email : Ridwandi080813@gmail.com
}

\begin{abstract}
ABSTRAK
Penelitian ini bertujuan untuk (1) mengidentifikasi perubahan penggunaan lahan. (2) mengidentifikasi perubahan fungsi bangunan. Penelitian ini menggunakan metode kuantitatif dengan pendekatan komparatif yang diperoleh dari data yang bersifat time series dengan lokasi penelitin pada kawasan sepanjang 850 meter dari pusat kampus IAIN Bukittinggi. Hasil penelitian menunjukkan bahwa sejak berdirinya IAIN tahun 2006 sampai sekarang (2016) berdampak terhadap perubahan pemanfaatan lahan (1) berubah sawah menjadi permukiman seluas 6,28 ha atau 39,6\%, semak belukar menjadi permukiman seluas 0,09 ha atau $0,58 \%$, tegalan menjadi permukiman seluas 1,56 ha atau 9,84\%, (2) perubahan fungsi bangunan yang terjadi adalah 16 rumah tinggal berubah fungsi menjadi rumah dan kos-kosan atau kos-kosan . Sejak kampus didirikan bangunan yang berdiri disekitar kampus banyak difungsikan untuk mendukung kegiatan kebutuhan kampus. Diperoleh kesimpulan bahwa terjadi perubahan pemanfaatan lahan dari non permukiman menjadi permukiman dan terjadi perubahan fungsi bangunan dari tempat tinggal menjadi kegiatan jasa, serta umunya bangunan yang didirikan setelah berdirinya kampus IAIN Bukittinggi berfungsi sebagai perdagangan dan jasa penunjang kegiatan kampus.
\end{abstract}

Kata Kunci:Perubahan pemanfaatan lahan

\section{ABSTRACT}

This study aims to (1) identify changes in land use. (2) identify changes in building functions. This study uses a quantitative method with a comparative approach obtained from time series data with the location of research in an area along the 850 meters from the center of the Bukittinggi IAIN campus. The results showed that since the establishment of the IAIN in 2006 until now (2016) had an impact on changes in land use (1) changing rice fields into settlements covering an area of 6.28 ha or $39.6 \%$, shrubs becoming settlements covering an area of 0.09 ha or $0.58 \%$, moorings become settlements covering an area of 1.56 ha or $9.84 \%$, (2) changes in the function of buildings that occur are 16 houses that change function into houses and boarding houses or boarding houses. Since the campus was established, buildings that stand around the campus have been used to support campus needs. It was concluded that changes in land use from non-settlements to settlements and changes in building functions from living quarters to service activities, and generally buildings that were established after the establishment of the Bukittinggi IAIN campus functioned as trade and campus activities support services.

Keywords: Changes in land use 


\section{PENDAHULUAN}

Penempatan suatu aktivitas baru sebagai aktivitas utama pada suatu kawasan pada umumnya akan diikuti aktivitas lain sebagai aktivitas pendukung, selanjutnya dengan berkumpulnya berbagai aktivitas pendukung maka suatu kawasan akan tumbuh dan berkembang.

Salah satu penempatan aktivitas utama adalah penempatan suatu perguruan tinggi (universitas). perguruan tinggi (universitas) sebagai wadah bagi masyarakat luas dalam menimba ilmu dapat menjadi pusat pertumbuhan baru yang menyebabkan multiplier effect terhadap kawasan sekitarnya. Sebagai institusi pendidikan, perguruan tinggi merupakan suatu komunitas masyarakat besar yang mempunyai kebutuhan akan barang dan jasa untuk menunjang segala aktivitasnya. Selain itu, perguruan tinggi (universitas) juga sering di definisikan sebagai mesin pembangunan ekonomi, dengan adanya perguruan tinggi, suatu kota ataupun daerah dapat menarik minat siswa untuk datang dan pada akhirnya mendatangkan pendapatan bagi kota/daerah tersebut. Hal ini akan memberi dampak pada peningkatan kepadatan bangunan dan jumlah penduduk dan pada akhirnya perubahan tersebut akan mempengaruhi pola penggunaan lahan dan fungsi bangunan sebagai kegiatan sosial dan kegiatan lainnya seperti adanya alih fungsi rumah tinggal dengan kegiatan ekonomi (sewa/kontrak kamar), perubahan/penambahan ruang dan bangunan guna menambah kapasitas, sedangkan perubahan penggunaan lahan terjadi guna memenuhi kebutuhan penduduk akan tempat tinggal dan tempat usaha sehingga lahan yang tadinya tidak terbangun menjadi terbangun.

\section{Penggunaan Lahan Dan Penutupan (tutupan) Lahan}

Terdapat perbedaan mendasar antara penggunaan lahan (land use) dan penutupan (tutupan) lahan (land cover). Penggunaan lahan berkaitan dengan aktivitas manusia yang secara langsung berhubungan dengan lahan. Dimana terjadi penggunaan dan pemanfaatan lahan dan sumberdaya yang ada serta menyebabkan dampak pada lahan.

Produksi tanaman, tanaman kehutanan, pemukiman perumahan adalah bentuk dari penggunaan lahan. Sementara, penutupan lahan berhubungan dengan vegetasi (alam atau ditanam) atau kontruksi oleh manusia (bangunan, dan lain-lain) yang menutupi permukaan tanah. Sebagai contoh, hutan, padang rumput, tanaman pertanian, rumah merupakan penutupan lahan.

Penutupan lahan adalah fakta dari fenomena sederhana yang dapat diamati di lapangan. Pada umumnya untuk studi pada skala semidetail atau yang skalanya lebih kecil terutama pada pemanfaatan data penginderaan jauh, istilah penggunaan lahan dan penutupan lahan biasanya dipadukan (Baja,2012).

Pengertian penggunaan lahan juga dikemukakan oleh Arsyad (1989:207), "Penggunaan lahan (land use) adalah setiap bentuk intervensi (campur tangan) manusia terhadap lahan dalam rangka memenuhi kebutuhan hidupnya baik materil 
maupun spritual". Penggunaan lahan dapat dikelompokkan kedalam dua golongan besar yaitu penggunaan lahan pertanian dan penggunaan lahan bukan pertanian.

Salah satu isu penggunaan lahan menurut Ahyuni (2016 ) adalah ketersediaan lahan untuk berbagai kebutuhan penduduk. Nilai lahan tergantung lokasinya, sehingga jika terjadi peningkatan nilai lahan maka akan terjadi penggunaan lahan dengan keuntungan optimal.

\section{Perubahan Pemanfaatan Lahan}

Lestari (2009), mendefenisikan alih fungsi lahan atau lazimnya disebut sebagai konversi lahan adalah perubahan fungsi sebagian atau seluruh kawasan lahan dari fungsi semula (seperti yang direncanakan) menjadi fungsi lain yang menjadi dampak negatif (masalah) terhadap lingkungan dan potensi lahan itu sendiri. Dampak alih fungsi lahan juga mempengaruhi struktur sosial masyarakat, terutama dalam struktur mata pencaharian

Perubahan penggunaan lahan adalah bertambahnya suatu penggunaan lahan dari satu sisi penggunaan ke penggunaan yang lainnya diikuti dengan berkurangnya tipe penggunaan lahan yang lain dari suatu waktu ke waktu berikutnya, atau berubahnya fungsi suatu lahan pada kurun waktu yang berbeda. (Wahyunto et al, 2001)

Saat ini fungsi pendidikan (perguruan tinggi) dengan skala lokal dan regional mewarnai karakter fungsi Kelurahan Pakan Labuah Kecamatan Aur Birugo Tigo Baleh Kota Bukittinggi Di kelurahan tersebut telah dibangun kampus Institut Agama Islam
Negeri (IAIN), yang dahulunya IAIN diberi nama STAIN Sjech M. Djamil Djambek Bukittinggi. IAIN Bukittinggi merupakan alih status dari Fakultas Syari'ah IAIN Imam Bonjol Bukittinggi Sumatera Barat.

Sejak beralih status dari Sekolah Tinggi menjadi Institut pada tahun 2014 sesuai dengan Keppres No.181 Tahun 2014, IAIN Bukittinggi terus melakukan pembangunan gedunggedung baru, dengan peralihan status ini tentu menambah minat siswa untuk masuk ke perguruan tinggi IAIN Bukittinggi, sehingga dengan berdirinya kampus IAIN Bukittinggi akan menimbulkan suatu konsekuensi terhadap sarana dan prasarana yang harus disediakan oleh pihak IAIN. Para mahasiswa dan para dosen serta pegawai memerlukan sarana pendukung, perumahan dan sarana jasa, sehingga membuka peluang bagi masyarakat sekitarnya untuk bisa menyediakan berbagai sarana dan prasarana tersebut. Kenyataan yang terjadi di sekitar Kampus IAIN Bukittinggi telah banyak berdiri gedung-gedung baru seperti perumahan dan Rumah Toko (Ruko). Berdirinya gedung baru di sekitar kampus berdasarkan pantauan penulis di lapangan sekitar kampus IAIN bahwa terlihat sawah berubah fungsi menjadi permukiman ( bangunan).

Dari banyaknya pembangunan yang dilakukan menyebabkan semakin berkurangnya lahan pertanian yang ada di sekitar kampus IAIN Bukittinggi pada area 850 meter dari pusat kampus.

Sebelum berdirinya kampus IAIN Bukittinggi tahun 2005 
penggunaan lahan Kelurahan Pakan Labuah masih di dominasi oleh pertanian.

Setelah berdirinya kampus IAIN Bukittinggi penggunaan lahan permukiman Tahun 2016 bertambah pada area sepanjang 850 meter dari pusat kampus IAIN Bukittinggi (Dinas Pekerjaan Umum Kota Bukittinggi).

Berdasarkan kondisi tersebut penulis ingin diketahui lebih jauh mengenai perubahan-perubahan penggunaan atau pemanfaatan lahan dan perubahan fungsi bangunan yang terjadi di Kelurahan Pakan Labuah khususnya disekitar kawasan kampus IAIN Bukittinggi dari tahun 2006-2016. Untuk itu penulis meneliti mengenai "Dampak Keberadaan Kampus Institut Agama Islam Negeri (IAIN) Bukittinggi terhadap Perubahan Pemanfaatan Lahan di Sekitarnya"

\section{METODE PENELITIAN}

Jenis penelitian ini adalah penelitian kuantitatif yaitu penelitian yang menekankan pada data-data numerikal (angka) yang diolah dengan metode statistika (Azwar, 2007: 5). Menurut Subana dan Sudrajat (2005: 25) penelitian kuantitatif dilihat dari segi tujuan, penelitian ini dipakai untuk menyajikan suatu fakta atau mendeskripsikan statistik, pada penelitian ini data yang disajikan berupa luas perubahan penggunaan lahan dan jumlah perubahan fungsi bangunan yang di analisis dari data-data penggunaaan lahan dan data bangunan.

Spesifikasi penelitian bersifat deskriptif yaitu untuk mengangkat fakta, keadaan, variabel, dan fenomena- fenomena yang terjadi sekarang (ketika penelitian berlangsung) dan penyajiannya apa adanya. Secara umum penelitian ini dilaksanakan di Kelurahan Pakan Labuah Kecamatan Aur Birugo Tigo Baleh Kota Bukittinggi dengan mengambil lokasi penelitin pada wilayah dengan radius 850 meter dari pusat kampus IAIN Bukittinggi. Sampel penelitian diambil 102 bangunan dari 183 bangunan yang ada.

Data diambil dengan menyebar angket kepada rumah penduduk untuk memperoleh informasi tentang fungsi bangunan dan tahun mendirikan bangunan. Data fungsi bangunan juga dimaksud untuk memperkuat data yang telah ada (data penggunaan Lahan) untuk melihat adanya pengaruh keberadaan kampus terhadap perubahan pemanfaatan lahan.

\section{HASIL DAN PEMBAHASAN}

\section{Penggunaan Lahan Wilayah Penelitian Tahun 2006}

Pembangunan yang berkembang pesat di Kelurahan Pakan Labuah terutama pada radius 850 meter dari pusat kampus IAIN Bukittinggi menyebabkan berubahnya pemanfaatan lahan di wilayah sekitarnya. Kelurahan Pakan Labuah memiliki area yang lebih dominan lahan pertanian yang dibuktikan dari data Dinas Pekerjaan Umum Kota Bukittinggi bahwa lahan pertanian Kelurahan Pakan Labuah tahun 2006 sebagai mana terlihat pada tabel 2.

Luas lahan pertanian/sawah seluas 100,48 ha merupakan angka tertinggi dibandingkan dengan luas penggunaan lahan yang lainnya. 
Penggunaan lahan sawah kelurahan Pakan Labuah tahun 2006 jika di persentasekan adalah $74,62 \%$ dari luas penggunaan lahan keseluruhan. Luas penggunaan lahan lainnya yaitu pemukiman seluas 18,1 ha $(13,4 \%)$ dari luas keseluruhan wilayah Kelurahan Pakan Labuah, luas Kolam 0,79 ha $(0,58 \%)$, lahan kosong seluas 0,21 ha $(0,16 \%)$, pemakaman seluas 1,53 ha $(1,13 \%)$, semak belukar seluas 5,92 ha $(4,27 \%)$, tegalan 7,78 ha $(5,77 \%)$, perkebunan 7,78 ha $(5,77 \%)$. Lahan yang paling luas pada penggunaan lahan Kelurahan Pakan Labuah Tahun 2006 adalah. Dari luas penggunaan Lahan Kelurahan Pakan Labuah pada Tahun 2006 terlihat masih banyak difungsikan sebagai pertanian atau lahan untuk bercocok tanam. Pemukiman masih tergolong sedikit.

Tabel 1. Luas Penggunaan Lahan Kelurahan

Pakan Labuah Tahun 2006

\begin{tabular}{lrr}
\hline $\begin{array}{l}\text { Penggunaan } \\
\text { Lahan }\end{array}$ & \multicolumn{1}{l}{$\begin{array}{l}\text { Luas } \\
\text { (ha) }\end{array}$} & \multicolumn{1}{c}{$\begin{array}{l}\text { Persentase } \\
\text { luas (\%) }\end{array}$} \\
\hline Pemukiman & 18,1 & 13,4 \\
\hline Kolam & 0,79 & 0,58 \\
\hline LahanKosong & 0,21 & 0,16 \\
\hline Pemakaman & 1,53 & 1,13 \\
\hline Sawah & 100,48 & 74,62 \\
\hline SemakBelukar & 5,92 & 4,27 \\
\hline Tegalan/perkebunan & 7,78 & 5,77 \\
\hline Luas total & 134,65 & $100 \%$
\end{tabular}

Sumber: Dinas Pekerjaan Umum Kota Bukittinggi Tahun 2006

\section{Penggunaan Lahan Wilayah dilakukan penghitungan luas dengan Penelitian Tahun 2016 menggunakan perangkat Arcgis. Luas \\ Penggunaan lahan tahun 2016 masing-masing penggunaan lahan dihasilkan dari pengolahan data shapfile Dinas Pekerjaan Umum Kota wilayah penelitian Tahun 2016 seperti terlihat pada tabel 2 .}

Bukittinggi. Dari data yang diperoleh
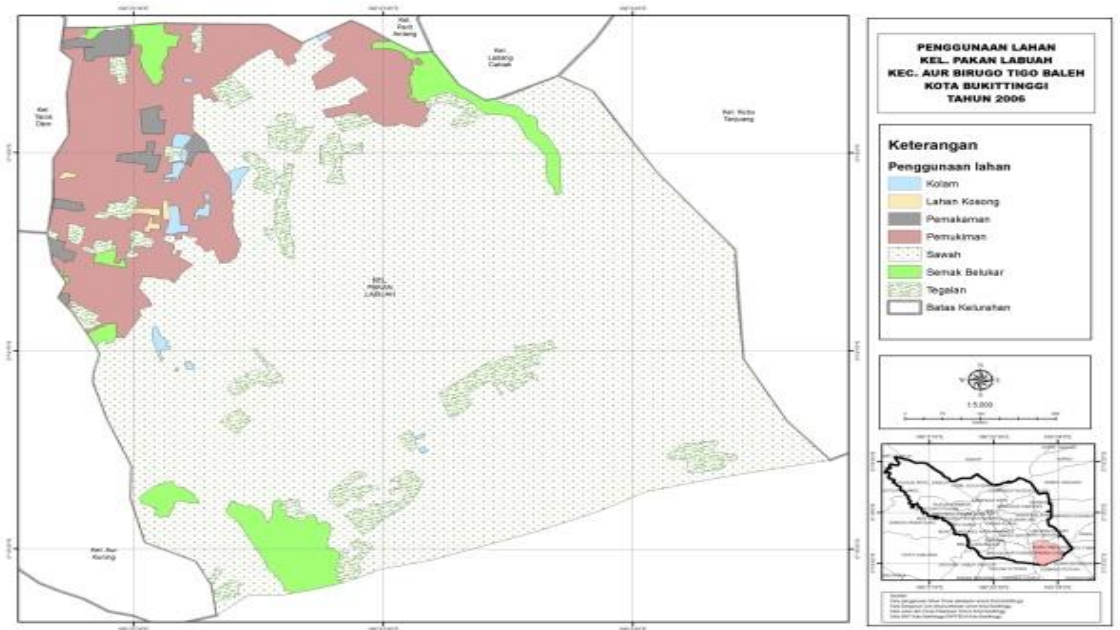

Gambar 1.Penggunaaan Lahan Kelurahan Pakan Labuah Tahun 2006 
Tabel 2. Luas Penggunaan Lahan Kelurahan Pakan Labuah Tahun Tahun 2016

\begin{tabular}{|c|c|c|}
\hline Penggunaan Lahan & $\begin{array}{l}\text { Luas } \\
\text { (ha) }\end{array}$ & $\begin{array}{l}\text { Persentase } \\
(\%)\end{array}$ \\
\hline Permukiman & 26,02 & 19,32 \\
\hline Kolam & 0,79 & 0,58 \\
\hline Lahan Kosong & 0.22 & 0,16 \\
\hline Pemakaman & 1,53 & 1,30 \\
\hline Sawah & 94,20 & 69,90 \\
\hline Semak Belukar & 5,67 & 4,20 \\
\hline Tegalan/perkebunan & 6,22 & 4,61 \\
\hline Luas total & 134,65 & 100 \\
\hline
\end{tabular}

Sumber: Pengolahan data shapfile Dinas Pekerjaan Umum Kota Bukittinggi 2016

Dari tabel 2 diketahui bahwa penggunaan lahan sawah/pertanian seluas 94,2 ha $(69,9 \%)$, penggunaan lahan pemukiman seluas 26,02 ha $(19,32 \%)$, penggunaan lahan kolam 0,79 ha $(0,58 \%)$, lahan kosong seluas 0,22 ha $(0,16 \%)$, pemakaman seluas 1,53 ha $(1,3 \%)$, luas lahan semak belukar seluas 5,67 ha $(4,2 \%)$, luas lahan tegalan/perkebunan seluas 6,22 ha $(4,61 \%)$.

Luas penggunaan lahan diolah berdasarkan shapfile yang telah diperoleh dari Dinas Pekerjaan Umum Kota Bukittinggi dengan menggunakan teknik Calculate geometry pada perangkat Arcgis. Penggunaan lahan tahun 2016 dapat dilihat pada gambar 2 .

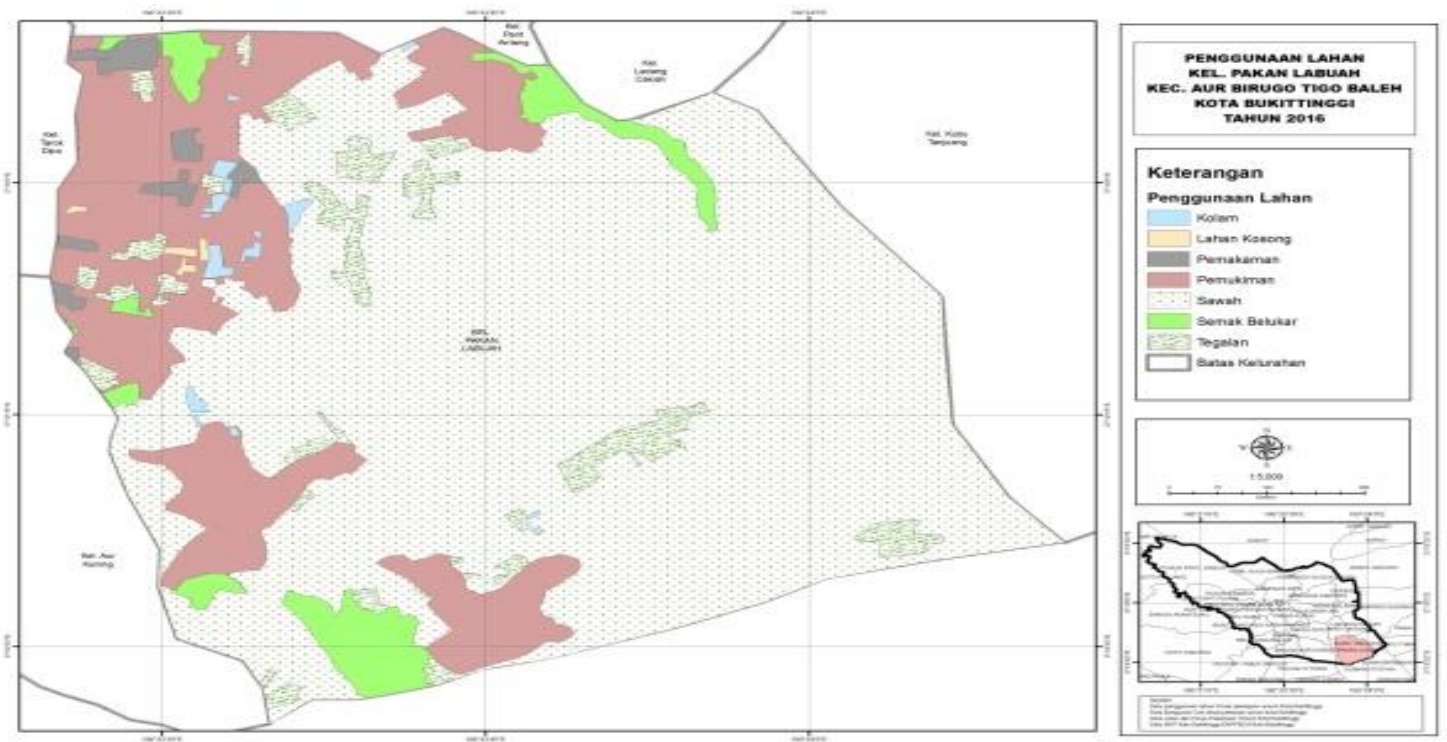

Gambar 2. Penggunaan Lahan Kelurahan Pakan Labuah Tahun 2016

\section{Perubahan Penggunaan Lahan} Keluran Pakan Labuah 2006-2016

Untuk melihat tingkat perubahan penggunaan lahan Kelurahan Pakan Labuah dilakukan teknik overlay (menggabungkan dua peta tahun berbeda). Peta dengan luas yang telah didapatkan dilakukan perbandingan perubahan yang terjadi. dengan cara mencari masing-masing luas penggunaan lahan tahun 2006 dan tahun 2016.

Tabel 3 merupakan hasil dari penghitungan perubahan luas 
penggunaan lahan kelurahan Pakan Labuah tahun 2006-2016. Pemukiman dengan luas lahan awal (2006) 18,1 ha berubah menjadi 26,02 ha (2016), pemukiman bertambah seluas 7,92 ha dengan persentase perubahan sebesar 49,9\% dari seluruh perubahan penggunaan lahan yang terjadi.

Tabel 3. Perubahan Luas Penggunaan

Lahan Kelurahan Pakan Labuah Tahun 2006-2016

\begin{tabular}{llccr}
\hline No & $\begin{array}{l}\text { Penggunaan } \\
\text { Lahan }\end{array}$ & $\begin{array}{l}\text { 2006 } \\
\text { (ha) }\end{array}$ & $\begin{array}{l}\text { 2016 } \\
\text { (ha) }\end{array}$ & Perubahan \\
\hline 1 & Pemukiman & 18,1 & 26,02 & 7,92 \\
\hline 2 & Kolam & 0,79 & 0,79 & - \\
\hline 3 & LahanKoson & 0,22 & 0,22 & - \\
& g & & & - \\
\hline 4 & Pemakaman & 1,53 & 1,53 & 6,28 \\
\hline 5 & Sawah & 100, & 94,2 & 0,09 \\
& & 48 & & 1,56 \\
\hline 6 & SemakBeluka & 5,75 & 5,67 & \\
\hline 7 & r & & & \\
\hline & Pegalan/ & 7,78 & 6,22 & \\
\hline Perkebunan & & & & \\
\hline
\end{tabular}

Sumber:Hasil Analisis

Luas lahan yang dimanfatkan untuk sawah berubah 6,28 ha pada tahun 2016. Sawah dengan luas 100,48 ha pada tahun 2006 mengalami pengurangan seluas 6,28 ha. Semak belukar pada tahun 2006 seluas 5,75 ha mengalami perubahan pada tahun 2016 yaitu seluas 0,09 ha. Tegalan/perkebunan pada tahun 2006 seluas 7,78 ha dan pada tahun 2016 luas lahan tegalan 6,22 ha. Luas lahan kolam dari tahun 2006 sampai tahun 2016 tetap 0,79 ha, tidak mengalami perubahan. Luas lahan kolam dan pemakaman tidak mengalami perubahan. Dari hasil penghitungan perubahan penggunaan lahan tahun 2006 dan tahun 2016 di kelompokkan perubahan menjadi tiga bagian, terlihat seperti pada tabel 4.

Tabel. 4 Perubahan Penggunaan Lahan

Menjadi Permukiman Kelurahan Pakan Labuah Tahun 2006-2016

\begin{tabular}{|c|c|c|}
\hline $\begin{array}{l}\mathbf{N} \\
\mathbf{0}\end{array}$ & $\begin{array}{l}\text { Perubahan } \\
\text { penggunaan Lahan }\end{array}$ & $\begin{array}{l}\text { Luas } \\
\text { (ha) }\end{array}$ \\
\hline 1 & $\begin{array}{ll}\text { Sawah } & \text { menjadi } \\
\text { permukiman } & \end{array}$ & 6,28 \\
\hline 2 & $\begin{array}{l}\text { Semak belukar menjadi } \\
\text { permukiman }\end{array}$ & 0,09 \\
\hline 3 & $\begin{array}{ll}\text { Tegalan } & \text { menjadi } \\
\text { permukiman } & \end{array}$ & 1,56 \\
\hline
\end{tabular}

Sumber: HasilPengolahan Data Sekunder.

Dari data perubahan penggunaan lahan dapat dijelaskan bahwa perubahan penggunaan lahan sawah menjadi permukiman seluas 6,28 ha.Perubahan semak belukar menjadi permukiman seluas 0,09 ha dan perubahan tegalan menjadi permukiman sebesar 1,56 ha Perubahan pengguna lahan dapat dilihat pada gambar 3 .
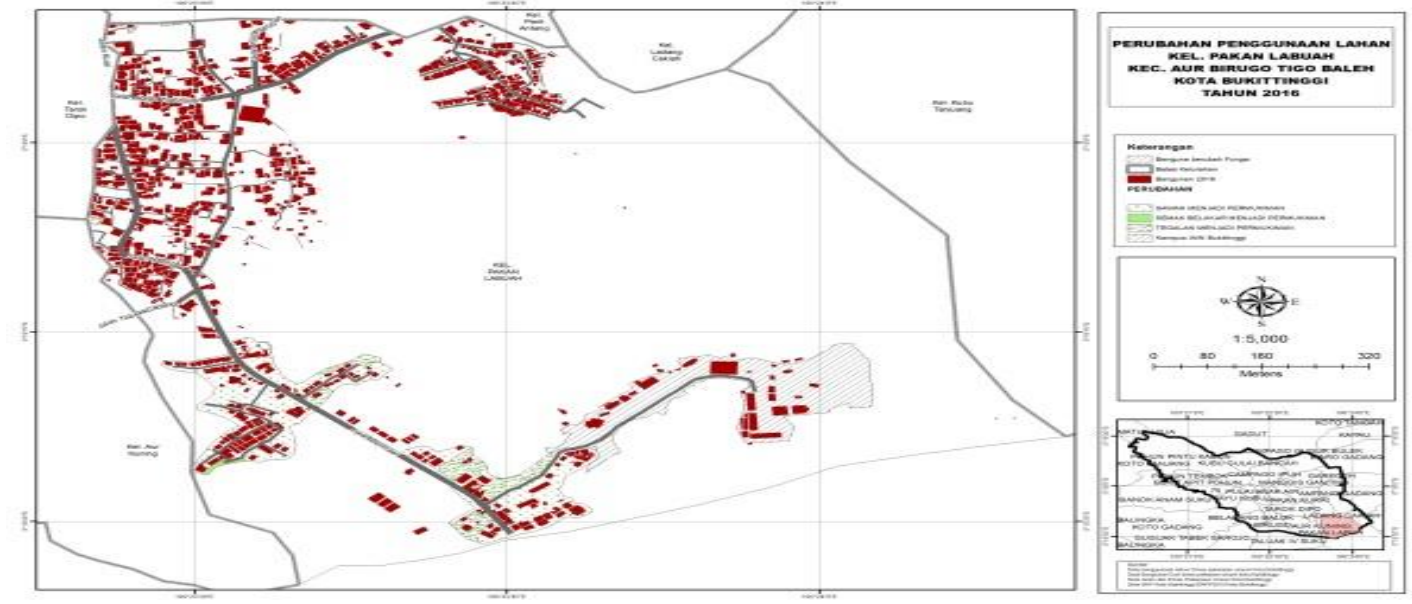

Gambar 3. Perubahan Penggunaan Lahan Tahun 2006-2016 
Perubahan Fungsi Bangunan yang Didirikan sampai Tahun 2005 di Wilayah Penelitian

Bangunan yang ada tahun 2005 atau sebelum berdirinya kampus IAIN Bukittinggi berjumlah sebanyak 14 bangunan pada area radius 850 meter dari pusat kampus. Dua belas (12) bangunan dari 14 bangunan tsb merupakan sebagian dari hasil pengambilan sampel bangunan yang dilakukan tahun 2016 yang berjumlah 102 bangunan. Sebanyak 12 bangunan tahun 2005 memiliki fungsi yang homogen yaitu sebagai rumah tempat tinggal.

Bangunan yang berdiri atau dibangun sampai tahun 2005 adalah bangunan yang berdiri sebelum berdirinya kampus IAIN Bukittinggi. Tidak ada perubahan fungsi bangunan pada tahun 2005 ke tahun 2006. Sehingga dapat disimpulkan pada tahun 2006 belum adanya pengaruh keberadaan kampus terhadap bangunan yang telah ada.

Tabel. 5 Fungsi Bangunan Tahun 2005

\begin{tabular}{cccc}
\hline No & $\begin{array}{c}\text { Nama } \\
\text { Pemilik }\end{array}$ & Tahun & Fungsi 2005 \\
\hline 1 & Widia & 2005 & Rumah Tempat Tinggal \\
\hline 2 & DediYulveri & 2005 & Rumah Tempat Tinggal \\
\hline 3 & Silvia & 2005 & Rumah Tempat Tinggal \\
\hline 4 & Asnedi & 2005 & Rumah Tempat Tinggal \\
\hline 5 & $\begin{array}{c}\text { Dr. H. David } \\
\text { Muzly }\end{array}$ & 2005 & Rumah Tempat Tinggal \\
& & \\
\hline 6 & $\begin{array}{c}\text { NadiatulFadil } \\
\text { ah }\end{array}$ & 2005 & Rumah Tempat Tinggal \\
\hline 7 & Mulyesi & 2005 & Rumah Tempat Tinggal \\
\hline 8 & Samra & 2005 & Rumah Tempat Tinggal \\
\hline 9 & Asnatuti & 2005 & Rumah Tempat Tinggal \\
\hline 10 & Netrawasni & 2005 & Rumah Tempat Tinggal \\
\hline 11 & Hanimar & 2005 & Rumah Tempat Tinggal \\
\hline 12 & Ernawati & 2005 & Rumah Tempat Tinggal \\
\hline
\end{tabular}

Sumber: HasilPengolahan Data Primer.

Perubahan fungsi 12 bangunan tahun lain yaitu menjadi rumah dan kos2005 tersebut ke tahun 2012 adalah kosan. sebanyak 3 bangunan berubah ke fungsi

Tabel 6. Perubahan Fungsi Bangunan sampai Tahun 2016 untuk Bangunan yang telah Berdiri sampai Tahun 2005

\begin{tabular}{|c|c|c|c|c|c|}
\hline \multirow[t]{2}{*}{ Tahun } & \multirow[t]{2}{*}{$\mathbf{J}$} & \multicolumn{2}{|l|}{ Fungsi 2012} & \multicolumn{2}{|c|}{ Fungsi 2016} \\
\hline & & Fungsi & $\mathbf{J}$ & Fungsi & $\mathbf{J}$ \\
\hline 2005 & 12 & $\begin{array}{l}\text { - Rumah tempat } \\
\text { tinggal }\end{array}$ & 9 & $\begin{array}{l}\text {-Rumah tempat } \\
\text { tinggal }\end{array}$ & 6 \\
\hline & & $\begin{array}{l}\text { - Rumah dan kos- } \\
\text { kosan }\end{array}$ & 3 & $\begin{array}{l}\text {-Rumah dan kos- } \\
\text { kosan }\end{array}$ & 6 \\
\hline
\end{tabular}

Selang tahun 2012-2016 terjadi lagi alih fungsi bangunan di sekitar kampus IAIN Bukittinggi untuk bangunan yang telah didirikan sampai tahun 2005 yaitu bertambahnya bangunan kos-kosan sebanyak 3 unit bangunan sehingga tahun 2016 rumah sekaligus kos-kosan berjumlah 6 bangunan. Total perubahan fungsi bangunan tahun 2005 ke tahun 2016 adalah adalah terjadi perubahan fungsi rumah tempat tinggal menjadi rumah dan kos-kosan. Perubahan fungsi bangunan dapat di jelaskan pada tabel 6 .

\section{Perubahan Fungsi Bangunan yang Didirikan Tahun 2006 di Wilayah Penelitian}

Setelah berdirinya kampus IAIN Bukittinggi yang diresmikan pada 
tanggal 27 Februari tahun 2006 (Sejarah STAIN Bukittinggi) dilihat dari perkembangan bangunan bahwa telah terjadi pertambahan bangunan baru di sekitar kampus IAIN Bukittinggi sebanyak 9 bangunan (data bangunan Kota bukittinggi Dinas Pekerjaan umum Kota Bukittinggi). Bangunan tersebut difungsikan sebagai rumah dan sebagai kos-kosan.

Dari hasil pengambilan data fungsi bangunan, terdapat 7 bangunan yang dibangun pada tahun 2006 sebagai Rumah tempat tinggal dan 2 bangunan yang dibangun untuk kos-kosan. Dari hasil survey dan wawancara diperoleh data bahwa bangunan yang berdiri pada tahun 2006 mengalami perubahan fungsi. Perubahan fungsi bangunan ini terjadi pada tahun 2012 dan tahun 2016. Perubahan fungsi bangunan ini dapat dilihat pada tabel 10 .

Dari tabel fungsi bangunan tahun 2006 diatas dapat dijelaskan bahwa telah terjadi perubahan fungsi bangunan pada tahun 2012 rumah tempat tinggal berubah fungsi menjadi rumah dan koskosan sebanyak 2 bangunan, sehingga bangunan rumah tempat tinggal berkurang menjadi 5 bangunan

Tabel. 7 Perubahan Fungsi Bangunan sampai Tahun 2016 untuk Bangunan yang Berdiri Tahun 2006

\begin{tabular}{|c|c|c|c|c|c|}
\hline \multicolumn{2}{|c|}{$\begin{array}{c}\text { Fungsi } 2006 \\
\text { (saat } \\
\text { didirikan) }\end{array}$} & \multicolumn{2}{|c|}{ Fungsi 2012} & \multicolumn{2}{|c|}{ Fungsi 2016} \\
\hline Fungsi & $\mathbf{J}$ & Fungsi & $\mathbf{J}$ & Fungsi & $\mathbf{J}$ \\
\hline $\begin{array}{l}\text {-Rumah } \\
\text { tempat } \\
\text { tinggal }\end{array}$ & 7 & $\begin{array}{l}\text {-Rumah } \\
\text { tempat } \\
\text { tinggal }\end{array}$ & 5 & $\begin{array}{l}\text {-Rumah } \\
\text { tempat } \\
\text { tinggal }\end{array}$ & - \\
\hline $\begin{array}{l}\text {-Kos- } \\
\text { kosan }\end{array}$ & 2 & $\begin{array}{c}\text {-Rumah } \\
\text { dan kos- } \\
\text { kosan } \\
\text {-Kos- } \\
\text { kosan }\end{array}$ & 2 & $\begin{array}{c}\text {-Rumah } \\
\text { dan } \\
\text { kost- } \\
\text { kosan } \\
\text {-Kost- } \\
\text { kosan }\end{array}$ & 4 \\
\hline
\end{tabular}

Sumber: hasil analisis

Bangunan yang berubah fungsi pada tahun 2016 adalah bangunan rumah tempat tinggal diubah fungsinya menjadi rumah dan kostkosan sebanyak 3 unit bangunan, dan menjadi kost-kosan sebanyak 2 unit bangunan, sehingga pada tahun 2016 tidak ada bangunan yang difungsikan sebagai rumah tempat tinggal saja, tapi rumah dan kos-kosan bertambah menjadi 5 unit dan kos-kosan menjadi 4 unit.

Perubahan Fungsi Bangunan yang Didirikan Tahun 2012 di Wilayah Penelitian

Dari data bangunan Kota Bukittinggi pada tahun 2012 telah bertambah bangunan sebanyak 35 bangunan pada area 850 meter dari pusat kampus IAIN Bukittinggi. Dari 35 bangunan peneliti mengambil sebanyak 26 bangunan yang didirikan tahun 2012 tersebut.

Dua puluh enam (26) bangunan yang berdiri tahun 2012 memiliki empat fungsi bangunan, diantaranya adalah difungsikan untuk rumah tinggal sebanyak 3 unit, koskosan sebanyak 15 unit bangunan, untuk Foto copy sebanyak 2 unit bangunan, untuk rumah sekaligus koskosan sebanyak 6 unit bangunan. Bangunan yang berdiri pada tahun 2012 ini mengalami perubahan fungsi pada tahun 2016, seperti terlihat pada tabel 8 . 
Tabel. 8 Perubahan Fungsi Bangunan sampai Tahun 2016 untuk Bangunan yang Berdiri

Sumber: analisis data fungsi bangunan

Perubahan yang terjadi pada tahun 2016 adalah rumah tempat tinggal berubah fungsi menjadi rumah dan kost-kosan sebanyak 3 unit bangunan.

\section{Fungsi Bangunan yang Didirikan Tahun 2012-2016 di Wilayah Penelitian}

Berdasarkan data bangunan dari Dinas Pekerjaan Umum Kota Bukittinggi tahun 2016 bangunan telah bertambah jumlahnya dari tahun 2012 disekitar kampus sebanyak 124 unit. Data fungsi bangunan tahun 2016 berdasarkan pengambilan data lapangan berupa sampel bangunan sebanyak 55 unit bangunan diperoleh bangunan yang difungsikan sebagai minimarket sebanyak 1 unit bangunan, rumah dan kost-kosan sebanyak 10 unit bangunan,

Tahun 2012

\begin{tabular}{clr} 
& \multicolumn{2}{c}{ Fungsi 2016 } \\
\hline J & \multicolumn{1}{c}{ Fungsi } & J \\
\hline 3 & -Rumah tempat & - \\
& tinggal & \\
6 & -Rumah dan & 9 \\
& kos-kosan & \\
15 & -Kos-kosan & 15 \\
2 & -Fotocopy & 2 \\
\hline
\end{tabular}

bangunan yang difungsikan sebagai foto copy sebanyak 10 bangunan, bangunan yang difungsikan sebagai conter handphone sebanyak 4 unit, yang difungsikan sebagai warung sebanyak 5 unit, bangunan yang difungsikan sebagai warnet sebanyak 4 unit bangunan, bangunan yang di fungsikan sebagai café sebanyak 1 unit bangunan, bangunan yang difungsikan sebagai apotik sebanyak 2 unit bangunan, bangunan yang difungsikan sebagai studio foto sebanyak 1 unit bangunan, dan bangunan yang di fungsikan sebagi kost-kosan sebanyak 17 bangunan.

Bangunan tersebut tidak mengalami perubahan fungsi bangunan, karena bangunan ini adalah bangunan yang baru di bangun sepereti terlihat pada tabel 9.

Tabel. 9 Fungsi Bangunan sampai Tahun 2016 untuk Bangunan yang Berdiri Tahun 2012-2016

\begin{tabular}{|c|c|c|c|}
\hline NO & Tahun & Fungsi Bangunan & $\mathbf{J}$ \\
\hline 1 & 2005 & Rumah tempat tinggal & 12 \\
\hline \multirow[t]{2}{*}{2} & \multirow[t]{2}{*}{2006} & Rumah Tempat tinggal & 7 \\
\hline & & Kos-kosan & 2 \\
\hline \multirow[t]{4}{*}{3} & \multirow[t]{4}{*}{2012} & Rumah tempat tinggal & 3 \\
\hline & & Kost-kosan & 15 \\
\hline & & Foto Copy & 2 \\
\hline & & Rumah dan Kost-kosan & 6 \\
\hline \multirow{10}{*}{4} & \multirow{10}{*}{2016} & Kost-kosan & 17 \\
\hline & & Foto Copy & 10 \\
\hline & & Rumah dan Koist-kosan & 10 \\
\hline & & Minimarket & 1 \\
\hline & & Conter Handphone & 4 \\
\hline & & Warung & 5 \\
\hline & & Warnet & 4 \\
\hline & & Café & 1 \\
\hline & & Apotik & 2 \\
\hline & & Studio Foto & 1 \\
\hline
\end{tabular}

Sumber: Hasil Analisis

Perubahan Fungsi Bangunan Tahun 2005, 2006 dan 2012
Pada tahun 2016 jumlah bangunan pada wilayah penelitian sebanyak 183 
bangunan. Jika pada tahun 2005 hanya berjumlah 14 unit maka terjadi peningkatan 13 kali lipat pada tahun 2016. Hal tersebut menyebabkan terjadinya perubahan penggunaan lahan. Disamping peningkatan jumlah bangunan juga ditemui fenomena perubahan fungsi bangunan. Perubahan fungsi bangunan yang terjadi di sekitar kampus IAIN Bukittinggi adalah terdapat 16 unit bangunan sampel yang berubah fungsi dari rumah tempat tinggal menjadi fungsi lain, yang terlihat seperti tabel 10.

Tabel 10. Perubahan Fungsi Bangunan sampai Tahun 2016

\begin{tabular}{|c|c|c|c|c|c|}
\hline \multirow[t]{2}{*}{$\mathrm{N}$} & \multirow{2}{*}{$\begin{array}{l}\text { Rumah } \\
\text { Tahun: }\end{array}$} & \multirow[t]{2}{*}{$\mathrm{j}$} & \multicolumn{2}{|l|}{ Perubahan 2016} & \multirow[t]{2}{*}{ sisa } \\
\hline & & & Fungsi rumah menjadi : & $\mathrm{J}$ & \\
\hline 1 & 2005 & 12 & - Rumah dan kos-kosan & 6 & 6 \\
\hline \multirow[t]{2}{*}{2} & 2006 & 7 & -kos-kosan & 2 & - \\
\hline & & & -Rumah dan kos-kosan & 5 & \\
\hline 3 & 2012 & 3 & -Rumah dan kos-kosan & 3 & - \\
\hline
\end{tabular}

Sumber: hasil olah data sampel bangunan

\section{PENUTUP}

\section{Kesimpulan}

Dengan berdirinya kampus IAIN

Bukittinggi sejak tahun 2006 hingga tahun 2016 disekitar kampus telah terjadi perubahan pemanfaatan lahan sawah ke lahan permukiman. Permukiman pada tahun 2006 dengan luas lahan 18,1 ha meningkat menjadi 26,02 ha. Perubahan fungsi bangunan yang terjadi di sekitar kampus IAIN Bukittinggi adalah telah berubah fungsi yaitu berubah untuk jasa sewa bangunan atau kos-kosan, sedangkan penggunaan bangunan lainnya digunakan untuk jasa penunjang dan jasa yang berkaitan dengan aktifitas Kampus IAIN Bukittinggi, yaitu seperti café, apotik, counter handphone, minimarket, warnet, warung, dan studio foto.

\section{Saran}

Pemerintah daerah sebaiknya memperhatikan laju pertumbuhan bangunan yang terjadi sebelum memberikan izin mendirikan bangunan, karena dengan meningkatnya laju pertumbuhan bangunan akan mengurangi penggunaan lahan lainnya. Pada Kelurahan Pakan Labuah telah terjadi perubahan lahan pemukiman yang dahulunya digunakan untuk lahan pertanian/sawah .Peran pemerintah sangat diperlukan untuk memantau kembali bangunan-bangunan yang didirikan dan dapat mempertimbangkan perizinan dengan melihat perubahan penggunaan lahan, sehingga lahan pertanian terselamatkan.

\section{DAFTAR RUJUKAN}

Ahyuni. 2016. Perencanaan Penggunaan Lahan. Jakarta: Kencana

Arsyad, Sitanala. 1989. Konservasi Tanah dan Air. Bogor : Institut Pertanian Bogor. 
Azwar, S. (2007). Metode Penelitian. Yogyakarta :Pustaka Belajar

Baja, S., 2012, Perencanaan Tata Guna Tanah dalam Pengembangan Wilayah Pendekatan Spasial dan Aplikasinya, Yogyakarta:.Andi Offset.

Lestari, T. 2009. Dampak Konversi Lahan Pertanian Bagi Taraf Hidup Petani. IPB. Bogor.

Subana, M dan Sudrajat, 2005, Dasar-Dasar Penelitian Ilmiah, Bandung: Pustaka Setia

Wahyunto, 2001, Studi Perubahan Lahan di Sub Das Citarik, Jawa Barat dan Kali Garang Jawa Tengah. Prosiding Seminar Nasional Multif 